\title{
Micromethod for the determination of uric acid in biological fluids
}

\author{
ROBERT G. MARTINEK ${ }^{1}$ \\ From the Clinical Chemistry Laboratory, Iowa Methodist Hospital, \\ Des Moines, Iowa, U.S.A.
}

SYNOPSIS A micro procedure for estimating uric acid in body fluids, based on the carbonate method, is described. Interferences are elucidated. The stoichiometry of the reaction is carefully worked out. Reliability of the method is established by comparison with two other methods, by recovery experiments, and by replicate analyses.

Most methods for the quantification of uric acid in biological fluids are based on the reducing power of this purine body. Uric acid has the ability to reduce the hexavalent tungsten of phosphotungstic acid to lower valences to form a blue colour. In principle, the reaction is similar to the one used for the estimation of glucose by the copper reduction technique and to the estimation of inorganic phosphorus. Since the resulting system is basically unstable, many workers have attempted to stabilize the final colour and prevent turbidity (Kern and Stransky, 1937; Caraway, 1955; Archibald, 1957; Henry, Sobel, and Kim, 1957; Eichhorn, Zelmanowski, Lew, Rutenberg, and Fanias, 1961).

This article is devoted to an elucidation of a modification of the carbonate method of Caraway (1955) resulting in smaller sample requirements, greater adherence to Beer's law, and much more rapid development of maximal colour with no loss in colour stability, thus making it more attractive for routine use.

\section{REAGENTS}

Chemicals of A.R. quality should be used where possible.

1 WORKING DEPROTEINIZING REAGENT Dissolve $1 \cdot 19 \mathrm{~g}$. of sodium pyrophosphate $\left(\mathrm{Na}_{4} \mathrm{P}_{2} \mathrm{O}_{7} \cdot 10 \mathrm{H}_{2} \mathrm{O}\right)$ and $15 \mathrm{mg}$. of metaphorphosic acid in about $50 \mathrm{ml}$. of water. Slowly add $1.45 \mathrm{ml}$. of concentrated sulphuric acid. Cool in a water bath to $40^{\circ} \mathrm{C}$. Slowly add $5.55 \mathrm{~g}$. of sodium tungstate $\left(\mathrm{Na}_{2} \mathrm{WO}_{4} \cdot \mathrm{SH}_{2} \mathrm{O}\right)$ dissolved in about $400 \mathrm{ml}$. of water. Make up with water to 1 litre. This solution is stable for at least five years at room temperature.

${ }^{1}$ Present address: 4736 N. Tripp Avenue, Chicago, Ill. 60630, U.S.A. Received for publication 14 May 1965.
$210 \%(\mathrm{w} / \mathrm{v})$ SOdium CARBonate Dissolve $100 \mathrm{~g}$. of anhydrous sodium carbonate in and dilute to 1 litre with water. Store in a polyethylene bottle. This solution is stable for at least one year at room temperature.

3 PHOSPHOTUNGSTIC ACID REAGENT Dissolve $10 \mathrm{~g}$. of sodium tungstate $\left(\mathrm{Na}_{2} \mathrm{WO}_{4} \cdot 2 \mathrm{H}_{2} \mathrm{O}\right)$ in $80 \mathrm{ml}$. of water. Add $8 \mathrm{ml}$. of $85 \%$ phosphoric acid. Boil gently with the aid of a reflux condenser fcr two hours. Allow to cool to room temperature and transfer to a 1 litre volumetric flask with the aid of water. Add about $40 \mathrm{Jl}$. of water and dissolve $16 \mathrm{~g}$. of lithium sulphate in the mixture. Dilute to 1 litre with water. Store in an amber glass bottle. This solution is stable for at least five years at room temperature.

4 URIC ACID STANDARD For the stock standard $(10 \mathrm{mg}$. per $100 \mathrm{ml}$.) dissolve $100 \mathrm{mg}$. of anhydrous uric acid and $50 \mathrm{mg}$. of lithium carbonate in about $150 \mathrm{ml}$. of water (warm if necessary). When completely dissolved, add about $500 \mathrm{ml}$. of water, $2.5 \mathrm{ml}$. of $40 \%$ formalin, and $0.3 \mathrm{ml}$. of glacial acetic acid. Make up to 1 litre with water. Store in an amber glass bottle. This solution is stable for at least one year at room temperature.

\section{METHOD}

To $2.7 \mathrm{ml}$. of working deproteinizing reagent in a test tube $(13 \times 100 \mathrm{~mm}$.) add $0.3 \mathrm{ml}$. of unhaemolysed serum, cerebrospinal fluid, or diluted urine (1:10 with water). Mix well by lateral shaking. Centrifuge at moderate speed for five minutes. Pipette $2.0 \mathrm{ml}$. of supernatant fluid and $1.0 \mathrm{ml}$. of $10 \%(\mathrm{w} / \mathrm{v})$ sodium carbonate into a round cuvette and mix. Let it stand for 10 minutes. Add $10 \mathrm{ml}$. of phosphotungstic acid reagent and immediately mix by lateral shaking. Within the next five to 23 minutes, read the absorbance at $700 \mathrm{~m} \mu$ against a partial reagent blank prepared by treating $2.0 \mathrm{ml}$. of water exactly as the supernatant fluid. Determine the concentration with reference to a $5 \mathrm{mg}$. per $100 \mathrm{ml}$. standard carried through 
the procedure at the same time, or by referring to a calibration curve prepared as described below. The colour is linear, up to $14 \mathrm{mg}$. per $100 \mathrm{ml}$. In the case of urine multiply by 10 to correct for the dilution.

For calibration, measure $2 \cdot 0,4 \cdot 0,6 \cdot 0,8 \cdot 0,10 \cdot 0,12 \cdot 0$, $14.0,16.0$, and $18.0 \mathrm{ml}$. of uric acid standard in 100 -ml. volumetric flasks. Dilute to the $100-\mathrm{ml}$. mark in each case with water. These standards are equivalent to protein-free filtrates $(1: 10)$ of biological fluids containing $2,4,6,8,10,12,14,16$, and $18 \mathrm{mg}$. $\%$ uric acid. Use 2.0 ml. of each standard in place of the supernatant fluid in the routine procedure above. This should be checked at regular intervals. A typical calibration curve is shown (Fig. 1). It can be seen that the reaction follows Beer's law to about $14 \mathrm{mg} . \%$ uric acid. In the Caraway (1955) procedure the colour is linear to only 8 to $10 \mathrm{mg} . \%$, depending on the instrument used.

All the figures quoted in this paper were obtained with a Coleman ${ }^{2}$ Junior spectrophotometer, model 6D using 19-mm. round cuvettes. To make readings on as little as $4 \mathrm{ml}$. of solution in 19-mm. round cuvettes, elevate them by placing a slice of solid rubber stopper at the bottom of the cuvette adaptor.

\section{EXPERIMENTAL}

OPTIMAL CONCENTRATIONS OF REAGENTS The sodium carbonate solution was varied in strength between $2 \%$ $(w / v)$ and $14 \%(w / v)$. These concentrations were tested in an actual serum assay. Similarly, the phosphotungstic acid concentration of that reagent was varied from 0.8 of the present concentration to 10 times the present concentration while keeping the sodium carbonate constant at $10 \%(\mathrm{w} / \mathrm{v})$. The results (Tables I and II)

${ }^{2}$ Coleman Instruments, Inc., Maywood, Ill., U.S.A.

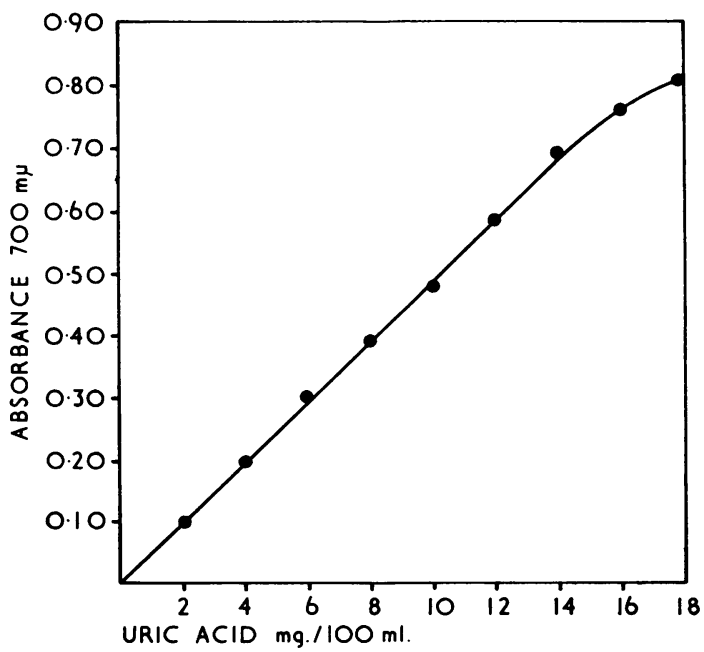

FIG. 1. Typical calibration curve obtained on a Coleman Junior spectrophotometer, model 6D, 19-mm. round cuvettes, reagent blank.
TABLE I

DETERMINATION OF OPTIMAL STRENGTH OF SODIUM CARBONATE SOLUTION

Sodium Carbonate Final Colour $(\%(w / v))$ (Absorbance)

\begin{tabular}{cc}
$\begin{array}{cc}\text { Sodium Carbonate } \\
(\%(w / v))\end{array}$ & $\begin{array}{c}\text { Final Colour } \\
(\text { Absorbance })\end{array}$ \\
\hline 2 & $0 \cdot 167$ \\
4 & $0 \cdot 191$ \\
5 & $0 \cdot 199$ \\
6 & $0 \cdot 209$ \\
8 & $0 \cdot 215$ \\
9 & $0 \cdot 222$ \\
10 & $0 \cdot 222$ \\
12 & $0 \cdot 222$ \\
14 & $0 \cdot 222$
\end{tabular}

TABLE II

DETERMINATION OF OPTIMAL STRENGTH OF PHOSPHOTUNGSTIC ACID REAGENT

Phosphotungstic Acid

Final Colour

Reagent (Times

Present Strength)

(Absorbance)

$\begin{array}{rr}10 & 0 \cdot 166 \\ 8 & 0 \cdot 133 \\ 6 & 0 \cdot 175 \\ 5 & 0 \cdot 199 \\ 4 & 0 \cdot 201 \\ 3 & 0 \cdot 209 \\ 2 & 0 \cdot 222 \\ 3 & 0 \cdot 222 \\ 0 \cdot 9 & 0 \cdot 222 \\ 0 \cdot 8 & 0 \cdot 222\end{array}$

indicate that both reagents are well within the optimal limits.

EFFECT OF PIGMENTS AND OTHER CONSTITUENTS IN SERUM Haemolysis must be avoided. Interfering materials are found largely in the cells and the red cells contain much less uric acid than serum. Bilirubin, up to $5.2 \mathrm{mg} . \%$ appears to exert no effect on the determination, nor does lipaemia.

Sodium oxalate, ammonium heparin, sodium citrate, $\overline{3}$ and the disodium salt of ethylenediamine tetracetic acid are all acceptable anticoagulants.

We found that salicylates spuriously raise serum values as much as $60 \%$. Many diuretic and antihypertensive을 agents, such as chlorothiazide, hydrochlorothiazide, bendroflumethiazide, and pyrazinamide, also have a을 tendency to elevate serum levels to as high as $12 \mathrm{mg} . \%$. It is best to have the patient taken off all drug therapy for $\mathbb{N}$ at least one week before drawing blood for this determin- $N$ ation.

\section{RESULTS}

RECOVERY OF ADDED URIC ACID If aqueous standards are admixed with serum before deproteinization, $\stackrel{+}{-}$ apparently a metastable solution of uric acid forms, $\frac{T}{T}$ with recoveries averaging only about $37 \%$ at levels $\frac{\text { P }}{\Phi}$ of 2.5 to $5.0 \mathrm{mg} . \%$ added uric acid (calculated final $\stackrel{\square}{\square}$ levels of 9.1 to $11.8 \mathrm{mg} . \%$ ). However, when we@ admixed pooled serum with a commercial controlo 
serum $^{3}$, the recoveries ranged from 97.5 to $102 \%$ (mean 99.0; $s \pm 1 \cdot 1$ ). Thus, uric acid appears to be adequately recovered from a physiological milieu. By a different approach, Caraway (1963) arrived at the same conclusion.

COMPARISON OF METHODS The present method was compared with that of Henry et al. (1957) and with the Caraway (1955) method. The results in Table III indicate excellent correlation between the three methods.

\section{TABLE III}

COMPARISON OF DIFFERENT SERUM URIC ACID METHODS

Serum No. Serum Uric Acid $(\mathrm{mg} . / 100 \mathrm{ml}$.)

\begin{tabular}{ll}
\hline Present & $\begin{array}{l}\text { Henry et al. Caraway (1955) } \\
\text { (1957) }\end{array}$
\end{tabular}

\begin{tabular}{lrrr}
\hline 1 & $2 \cdot 1$ & $2 \cdot 1$ & $2 \cdot 1$ \\
2 & 6.6 & 6.6 & $6 \cdot 6$ \\
3 & $11 \cdot 2$ & $11 \cdot 2$ & $11 \cdot 2$ \\
4 & 12.7 & 12.9 & 12.7 \\
5 & 13.9 & 13.5 & 13.9 \\
Mean & 9.3 & 9.3 & 9.3
\end{tabular}

REPRODUCIBILITY Twenty-five sera were analysed in duplicate. The standard deviation, calculated by the formula of Henry and Dryer (1963), $s=\sqrt{\frac{\sum\left(\mathrm{d}^{2}\right)}{\mathrm{N}}}$ (d = difference between duplicates; $\mathrm{N}=$ total number of determinations), was \pm 0.07 for the present method. A similar statistical treatment of 20 cerebrospinal fluid samples (with normal levels of uric acid) and 20 urine samples resulted in standard deviations of \pm 0.10 and \pm 0.08 , respectively.

STABILITY OF URIC ACID IN BODY FLUIDS Uric acid is stable in serum and cerebrospinal fluid for at least 24 hours at room temperature (approx. $25^{\circ} \mathrm{C}$.),

${ }^{3}$ Versatol-A, General Diagnostics Division, Warner-Chilcott Div., Morris Plains, N.J., U.S.A. for at least one month in the refrigerator (approx. $5^{\circ} \mathrm{C}$.), and at least four months in the freezer (approx. $-15^{\circ} \mathrm{C}$.).

The stability of uric acid in unpreserved urine is variable. By saturating with toluene, uric acid may be preserved in urine for several days in the refrigerator (approx. $5^{\circ} \mathrm{C}$.).

NORMAL VALUES Ninety-five per cent limits were calculated using $\mathrm{K}$ factors as described by Henry and Dryer (1963).

The $95 \%$ limits for serum uric acid were $3 \cdot 1$ to $7.0 \mathrm{mg} . \%$ for males and 2.0 to $5.9 \mathrm{mg} . \%$ for females. In urine, the $95 \%$ limits were 0.1 to $2.0 \mathrm{~g}$. per 24 hours but no sex difference was found.

The $95 \%$ 'normal' limits for cerebrospinal fluid uric acid were 0.2 to $0.3 \mathrm{mg}$. $\%$. No sex difference was determined.

\section{DISCUSSION}

Lithium sulphate was included in the phosphotungstic acid reagent merely on the suggestion of Henry et al. (1957). We found its use unnecessary, in limited testing, since we experienced no turbidity in the final coloured mixture regardless of its use or deletion. We retained it, however, as prophylaxis against some yet unencountered serum interference which might produce problems with clarity in the final colour.

\section{REFERENCES}

Archibald, R. M. (1957). Clin. Chem., 3, 102.

Caraway, W. T. (1955). Amer. J. clin. Path., 25, 840.

- (1963). In Standard Methods of Clinical Chemistry, edited by D. Seligson, vol. 4, pp. 239-247. Academic Press, New York.

Eichhorn, F., Zelmanowski, S., Lew, E., Rutenberg, A., and Fanias, B. (1961). J. clin. Path., 14, 450.

Henry, R. J., and Dryer, R. L. (1963). In Standard Methods of Clinical Chemistry, edited by D. Seligson, vol. 4, pp. 205-237. Academic Press, New York.

_- Sobel, C., and Kim, J. (1957). Amer. J. clin. Path., 28, 152.

Kern, A., and Stransky, E. (1937). Biochem. Z., 290, 419. 